\title{
Badminton Competition Aplication Using Website
}

\author{
Nyimas Sopiah", Devrhi Setiawan ${ }^{2}$
}

\author{
${ }^{1}$ Fakultas Ilmu Komputer, Universitas Bina Darma, Palembang, Indonesia \\ 2,3Program Studi Teknik Informatika, Universitas Bina Darma, Palembang, Indonesia \\ Email: ${ }^{1}$ nyimas.sopiah@binadarma.ac.id
}

\begin{abstract}
Persatuan Bulu Tangkis Seluruh Indonesia (PBSI) is an organization that manages the game of badminton in Indonesia. The Palembang branch of PBSI has so far held a competition that has not used special software, from registration to the results of the competition. The problem that often occurs is the frequent occurrence of misinformation about the race. For this reason, an application will be made that can help accommodate the race administration, starting from the registration of the race to the results of the race. Application created using the website. The development method used in making applications is the Web Engineering method. The programming language used is using PHP and the database is used using MySql. The results of this study are expected to make it easier for athletes to see information about race events, match schedules, race registration, making it easier for badminton clubs to register their athletes in competitions held by PBSI.
\end{abstract}

Keywords: Application, Website, Web Engineering.

\section{PENDAHULUAN}

PBSI Kota Palembang merupakan salah satu cabang Persatuan Bulu Tangkis seluruh Indonesia. PBSI Kota Palembang sering mengadakan kegiatan perlombaan bulu tangkis. Sejauh ini promosi kegiatan lomba dilakukan dengan menyebarkan informasi melalui orang-orang tertentu saja yang dengan dekat dengan pihak PBSI Kota Palembang. Sehingga menyebabkan atlet sering bertanya-tanya kapan perlombaan akan diadakan. Hal ini menyebabkan atlet kurang persiapan untuk menghadapi perlombaan yang baru diketahui jadwalnya. Selain dari itum atlet juga sering bertanya-tanya kepada panitia loba kapan atlet akan bertanding.

Kendala yang sering muncul adalah kurangnya informasi dari pihak panitia mengenai jadwal perlombaan, misalnya jadwal perlombaan yang semula pukul 21.00 tetapi terlaksana pukul 03.00 pagi. Hal ini menyebabkan atlet sudah tidak semangat lagi untuk melanjutkan perlombaan disebabkan oleh menunggu yang terlalu lama atau tidak sesuai dengan jadwal yang telah diinformasikan sebelumnya. Selain dari masalah tersebut, PBSI Kota Palembang terdapat masalah lain yaitu sulitnya mendata atlet di Kota Palembang, karena 
ketidaktahuan atlet di mana tempat mendaftar dan apa saja syaratnya. Hal ini disebabkan karena kurangnya infomari terhadap layanan mengenai hal tersebut dari pihak PBSI Kota Palembang kepada masyarakat, atlet atau komunitas klub bulu tangkis di kota ini. Jika tidak terdaftar sebagai atlet di PBSI Kota Palembang, maka atlet tidak berhak untuk melakukan pendaftaran perlombaan di PBSI Kota Palembang.

Berdasarkan permasalah di atas, maka dibuatkanlah aplikasi yang membantu kegiatan perlombaan bulu tangkis, dimulai dari pendaftaran perlombaan sampai dengan pengumuman hasil lomba. Metode pengembangan aplikasi untuk menyelesaikan masalah di atas adalah menggunakan metode web engineering. Bahasa pemrograman yang digunakan dalam penelitian ini menggunakan PHP (Personal Hypertext).

Penelitian yang telah dibuat oleh Yulianta dan Petrus Mursanto (1) menghasilkan website. Penelitiannya mengembangkan sistem manajemen isi pada PT X yang dinamai dengan xCMS. Metode pengembangan perangkat lunak yang digunakan adalah ICONIX Process. Hasil akhirnya adalah sebuah prototipe aplikasi manajemen isi aplikasi web yang diberi nama xCMS.

Penelitian berikutnya menggunakan web engineering sebagai metode pengembangan perangkat lunaknya. Penelitiannya menghasilkan aplikasi penjualan kain khas Palembang. Metode perancangan menggunakan Unified Modelling Language (UML) (2).

\section{METODOLOGI PENELITIAN}

Ada beberapa metode yang digunakan dalam penelitian ini. Berikut uraian dari metode-metode yang dipakai.

\subsection{Objek Penelitian}

Objek dari penelitian ini adalah Persatuan Bulu Tangkis Seluruh Indonesia (PBSI) Kota Palembang.

\subsection{Metode Pengumpulan Data}

Metode pengumpulan data yang digunakan dalam penelitian ini terdiri dari beberapa bagian, yaitu:

1) Wawancara. Penelitian ini mengumpulkan data dengan mengadakan wawancara kepada PBSI Kota Palembang, khususnya panitia yang berkaitan dengan lomba bulu tangkis.

2) Pengamatan. Pengamatan dilakukan dengan mengamati kegiatan yang dilakukan, dimulai dari melakukan pendaftaran untuk menjadi atlet, mengikuti perlombaan dan pengumuman hasil lomba.

3) Studi Literatur. Studi literatur merupakan salah satu bagian yang digunakan untuk mendapatkan informasi yang berkaitan dengan penelitian ini. Studi 
dilakukan mulai dari pengumpulan data-data mengenai teori-teori yang berkaitan dengan penelitian.

\subsection{Metode Pengembangan Aplikasi}

Metode pengembangan aplikasi yang digunakan dalam penelitian ini adalah $W e b$ Engineering. Metode Web Engineering adalah metode yang digunakan di dalam pembuatan perangkat lunak. Web Engineering merupakan proses yang digunakan untuk menciptakan web aplikasi berkualitas tinggi (1). Metode web engineering mempunyai 5 (lima) tahap di dalam pengembangan perangkat lunak yaitu: 1) Customer communication. Komunikasi di sini adalah mengadakan komunikasi dengan pihak PBSI Kota Palembang. Tahap ini terdiri dari 3 bagian yaitu formulasi, negosiasi dan elisitasi. 2) Planning, tahap ini dilakukan dengan cara melakukan perencanaan segala kebutuhan dari pengembangan aplikasi ini. 3) Modeling. Tahap ini melakukan analisis terhadap sistem yang berjalan, menganalisa kebutuhan sistem yang akan dikembangkan, serta membuat rancangan (design) struktur tabel basis data dan rancangan struktur menu serta tampilan informasi. 4) Construction. Tahap ini merupakan tahap pembangunan web menggunakan pengkodean (coding). 5) Deployment. Tahap ini merupakan tahap penyebaran aplikasinya Sehingga dapat diuji dan dievaluasi apa kendala dari perangkat lunak tersebut.

\subsection{Alat Bantu Perancangan}

Perancangan dalam penelitian ini menggunakan perancangan terstruktur yaitu dengan menggunakan Data Flow Diagram (DFD) dan Entity Relationship Diagram (ERD).

\section{HASIL DAN PEMBAHASAN}

\subsection{Customer Communication (Komunikasi Konsumen)}

Tahap ini terdiri dari 3 bagian. Pertama adalah formulasi. Tahap ini mempunyai kegiatan dengan mendefinisikan kebutuhan bisnis, mendeskripsikan objek yang dibangun dan menentukan ditur-fitur yang akan digunakan dalam pembuatan aplikasi. Penelitian ini dilakukan dengan mempunyai kebutuhan perangkat keras (hardware) dengan memakai Personal Computer (PC). Perangkat lunaknya untuk membangun aplikasi ini dengan menggunakan bahasa pemrograman PHP dan database menggunakan MySQL. Sedangkan kebutuhan manusia adalah peneliti sendiri. Objek yang akan dibangun adalah dengan membuat aplikasi yang mendukung kegiatan dimulai dari pendaftaran sampai dengan pengumuman hasil lomba bulu tangkis. Sedangkan fitur-fitur aplikasi dibuat sebagai prototyping (pemodelan) sebelum hasil akhir sudah disetujui.

Tahap kedua adalah negosiasi. Tahap ini merupakan tahap bernegosiasi dengan pihak PBSI Kota Palembang. Setelah dibuatkan prototyping, maka hasilnya 
adalah melakukan negosiasi dengan pihak pengguna atau pihak PBSI Kota Palembang. Dimulai dari proses bisnis sampai dengan fitur-fitur penggunaan aplikasi. Tahap ini menghasilkan beberapa hal berikut. Sistem yang akan dikembangkan harus bisa melayani pelatih dalam mengurus atlet ditinjau dari kegiatan pendaftaran atlet sampai dengan pendaftran kegiatan lomba. Sistem yang akan dibangun juga harus bisa melayani mitra dalam melakukan usulan kegiatan lomba. Sistem yang akan dibangun juga harus bisa meng-update informasi terbaru tentang lomba. Sistemnya juga harus bisa menampilkan informasi urutan rangking atlet ketika perlombaan telah selesai.

Tahap ketiga adalah elisitasi. Tahap ini melakukan pertemuan antara pengembangan dan klien (pengguna) sistem.

\subsection{Planning (Perencanaan)}

Tahap perencanaan (planning) merupakan tahap yang dilakukan untuk merencanakan kebutuhan yang dieprlukan dalam pengembangan pembuatan aplikasi ini. Tahap ini terdiri dari beberapa bagian, yaitu estimasi, analisis resiko, penjadwalan dan monitoring. Estimasi pengembangan aplikasi dimulai dari bulan Januari 2019 sampai dengan Mei 2019. Estimasi sumber daya terdiri dari estimasi penggunakan perangkat keras dan perangkat lunak. Analisis resiko terdiri dari beberapa resiko, yaitu resiko pengguna, produk dan proses. Penjadwalan dilakukan berdasarkan tahapn pengembangan dari web engineering. Monitoring dilakukan untuk mengawasi kegiatan pengembangan aplikasi dari setiap kegiatan dalam tahap web engineering apakah sesuai dengan perencanaan atau tidak.

\subsection{Modelling (Pemodelan)}

Tahap pemodelan yang dilakukan dengan membuat rancangan Data Flow Diagram (DFD) dan Entity Relationship Diagram (ERD).

\subsubsection{Data Flow Diagram (DFD)}

Data Flow Diagram (DFD) merupakan alat bantu untuk merancang aliran data pada aplikasi yang dirancang. DFD ini mempunyai external entity yaitu Pelatih, Mitra dan Keabsahan \& IT. Prosesnya ada sembilan yaitu login, kelola pengguna, pendaftaran, event, pertandingan, rangking atlet, materi latihan, chat, dan pencetakan laporan. Sedangkan data store nya ada tujuh belas, yaitu pengguna, club, atlet, referee, wasit, hakim garis, mitra, event, kategori event, pendaftaran event, wasit event, hakim garis event, hasil pertandingan event, rangking atlet, materi latihan, chat pelatih, dan chat mitra. DFD pada pengembangan aplikasi ini dapat dilihat pada gambar 1 berikut. 
Journal of Information Systems and Informatics

Vol. 2, No. 2, September 2020

p-ISSN: 2656-5935 http://journal-isi.org/index.php/isi e-ISSN: 2656-4882

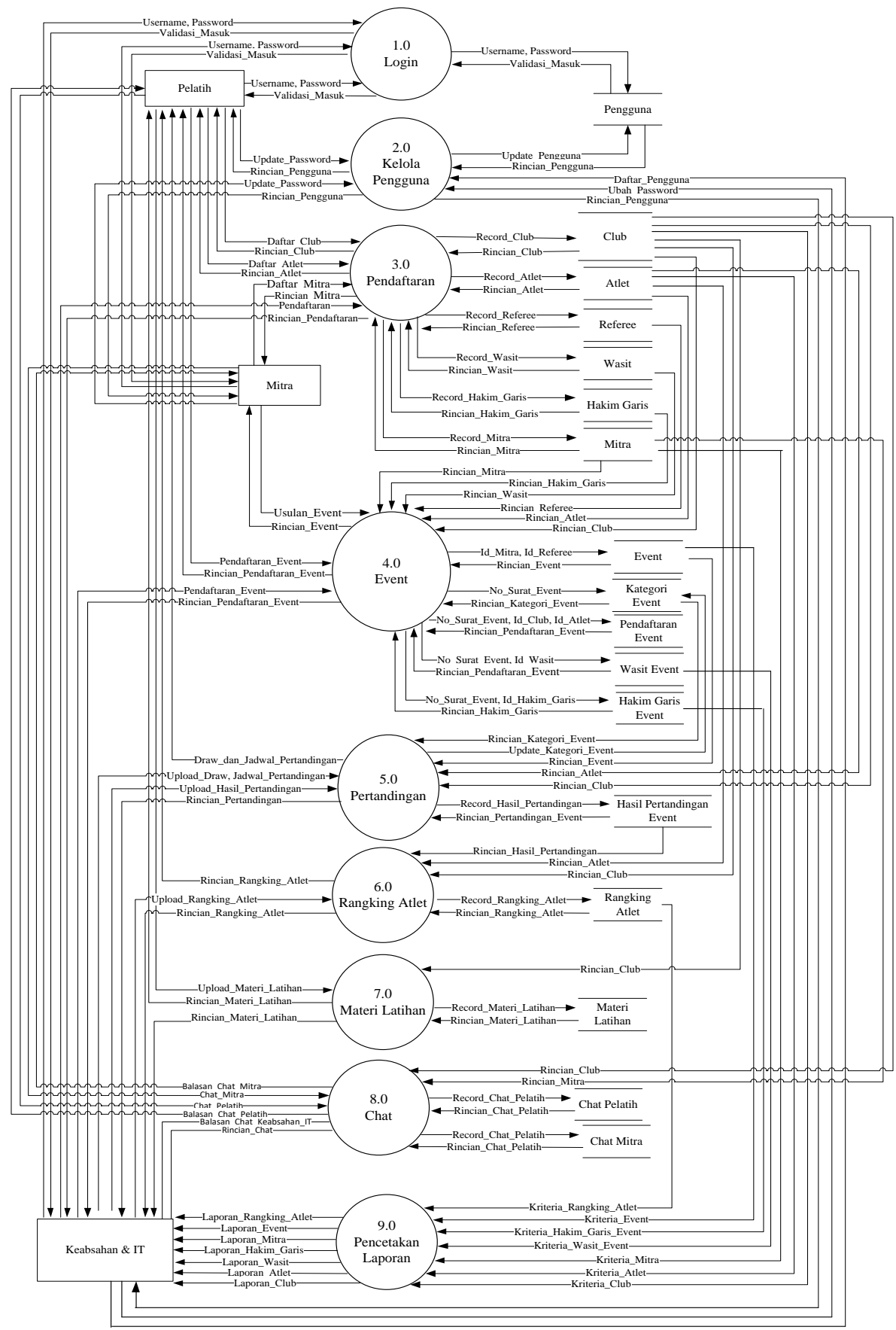

Gambar 1. Data Flow Diagram (DFD)

316 | Badminton Competition Aplication Using Website 
Vol. 2, No. 2, September 2020

p-ISSN: XXX-XXX http://journal-isi.org/index.php/isi

e-ISSN: XXX-XXX

\subsubsection{Entity Relatinship Diagram (ERD)}

Entity Relationship Diagram adalah diagram yang berisi komponen-komponen himpunan entitas dan himpunan relasi yang masing-masing dilengkapi dengan atribut-atribut yang mempresentasikan seluruh fakta yang ditinjau (2). Data store yang ada di DFD sama dengan entitas di ERD, maka entitas di ERD terdiri dari tujuh belas entitas. ERD dalam penelitian ini dapat dilihat pada gambar 2 berikut.

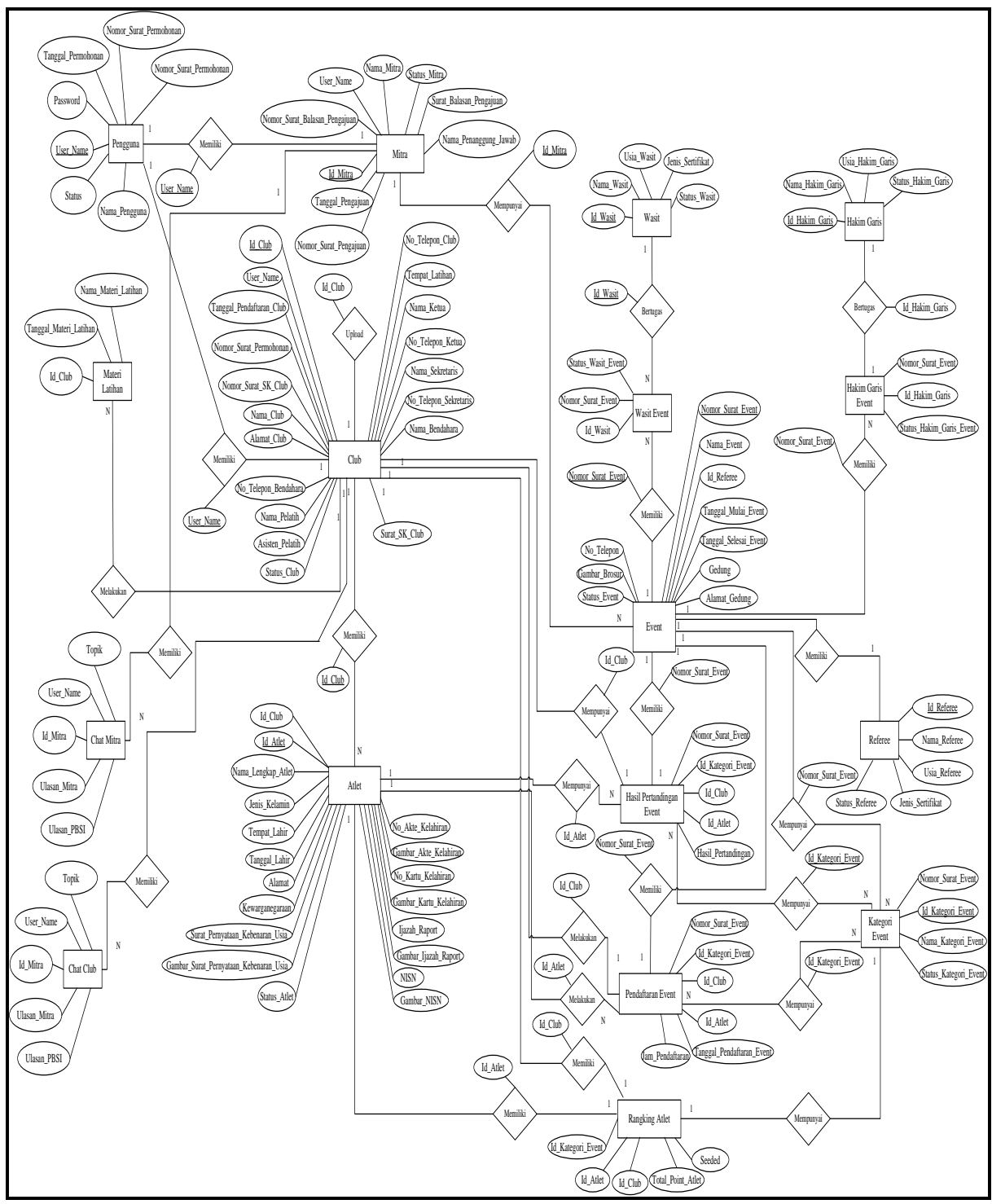

Gambar 2. Entity Relationship Diagram (ERD) 
Vol. 2, No. 2, September 2020

p-ISSN: 2656-5935 http://journal-isi.org/index.php/isi

e-ISSN: $2656-4882$

\subsubsection{Rancangan Basis Data}

Sesuai denga rancangan sebelumya yaitu DFD dan ERD, maka tabel dari basis data dalam penelitian ini terdiri dari 17 tabel yaitu pengguna, club, atlet, referee, wasit, hakim garis, mitra, event, kategori event, pendaftaran event, wasit event, hakim garis event, hasil pertandingan event, rangking atlet, materi latihan, chat pelatih, dan chat mitra.

\subsection{Construction (Konstruksi)}

Tahap ini merupakan tahap pengkodean menggunakan bahasa pemrograman PHP. Hasil dari pengkodean ini dapat diuraikan sebagai berikut.

\subsubsection{Tampilan Pengguna}

Tampilan daftar pengguna merupakan tampilan untuk memasukkan pengguna baru. Pengguna di sini adalah Keabsahan \& IT (pengelola web, atlet, mitra, dan pelatih. Berikut salah satu contoh untuk memasukkan data pengguna mitra.

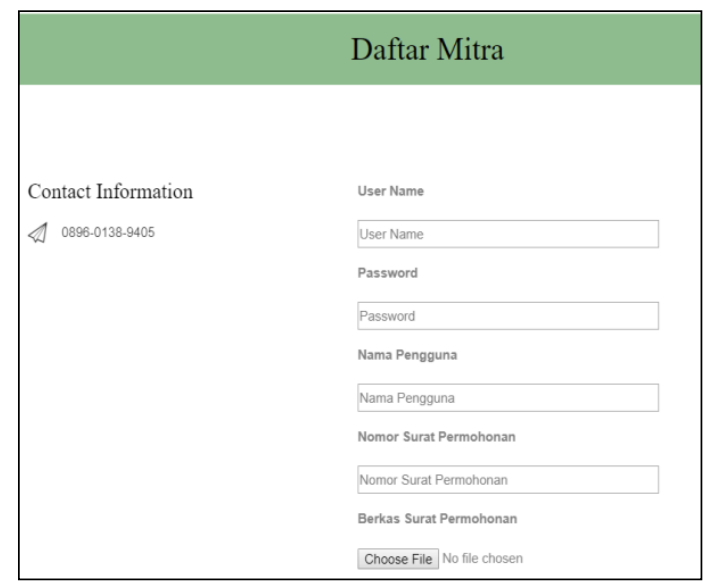

Gambar 3. Tampilan Pengguna Mitra

\subsubsection{Tampilan Chat}

Tampilan chat merupakan tampilan untuk berkomunikasi dengan beberapa pengguna, yaitu mitra dan pelatih. Berikut salah satu contoh tampilan chat dengan mitra, dapat dilihat pada gambar 4. 
Vol. 2, No. 2, September 2020

p-ISSN: XXX-XXX http://journal-isi.org/index.php/isi e-ISSN: XXX-XXX

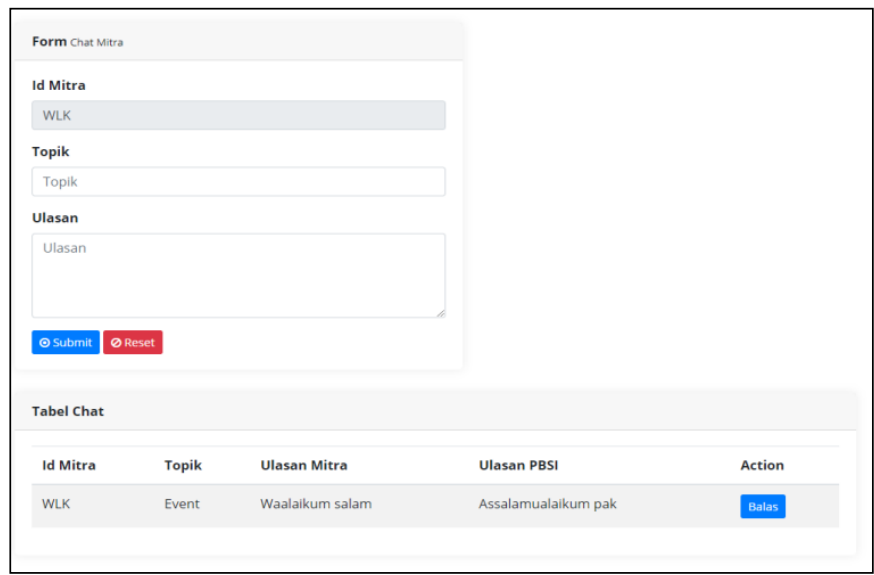

Gambar 4. Tampilan Chat Mitra

\subsubsection{Tampilan Usulan Event}

Tampilan usulan event merupan tampilan yang digunakan oleh mitra untuk memberikan usulan perlombaan kepada PBSI Kota Palembang. Gambar 5 merupakan tampilan dari usulan event.

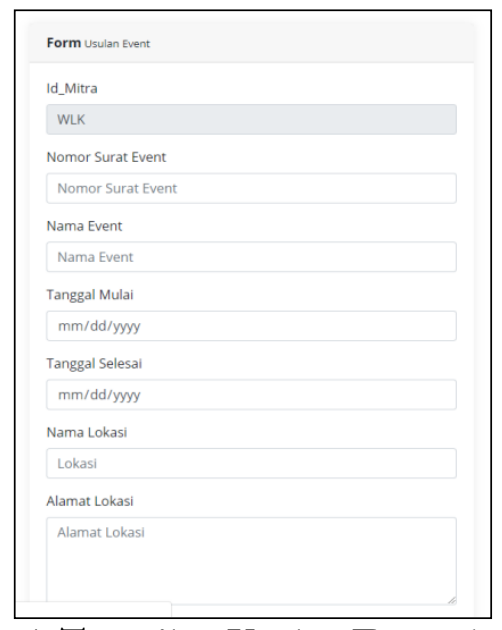

\section{Gambar 5. Tampilan Usulan Event dari Mitra}

Setelah diusulkan oleh mitra, maka pihak PBSI Kota Palembang akan mempertimbangkan apakah usulan tersebut akan diterima (acc) atau tidak.

\subsubsection{Tampilan Input}

Tampilan input merupakan tampilan untuk memasukkan data club, atlet, referee, hakim garis, kategori event, wasit event, dan hakim garis event. Gambar 6 merupakan salah satu contoh tampian input data referee. 
Vol. 2, No. 2, September 2020

p-ISSN: 2656-5935 http://journal-isi.org/index.php/isi e-ISSN: 2656-4882

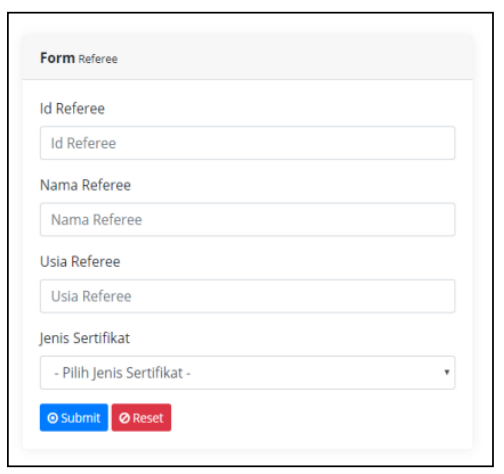

\section{Gambar 6. Tampilan Input data Referee}

\subsubsection{Tampilan Pendaftaran mengikuti Perlombaan (Event)}

Pendaftaran Perlombaan merupakan tampilan yang digunakan oleh pelatih untuk mengikut perlombaan di PBSI Kota Palembang. Gambat 7 merupakan contohnya.

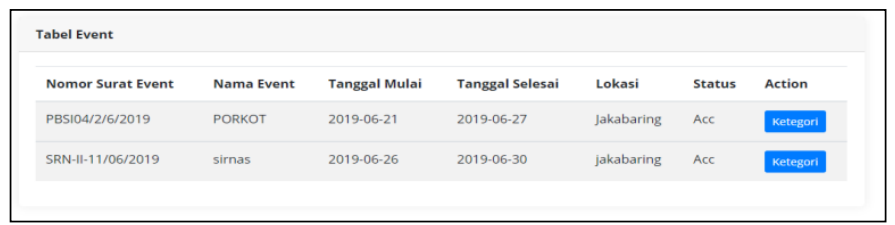

Gambar 7. Tampilan Pendaftaran Perlombaan

\subsubsection{Tampilan Jadwal Perlombaan}

Tampilan jadwal perlombaan merupakan tampilan yang menampilan informasi mengenai jadwal lomba yang diadakan oleh PBSI Kota Palembang. Gambar 8 menampilkan jadwal perlombaan.

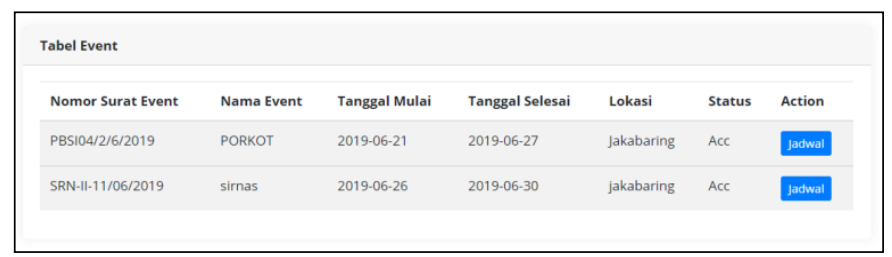

Gambar 8. Tampilan Jadwal Perlombaan

\subsubsection{Tampilan Draw Pertandingan}

Tampilan draw pertandingan merupakan tampilan untuk melakukan draw pertandingan pada Sistem PBSI Kota Palembang. Berikut merupakan tampilan form draw pertandingan. 
Vol. 2, No. 2, September 2020

p-ISSN: XXX-XXX http://journal-isi.org/index.php/isi e-ISSN: XXX-XXX

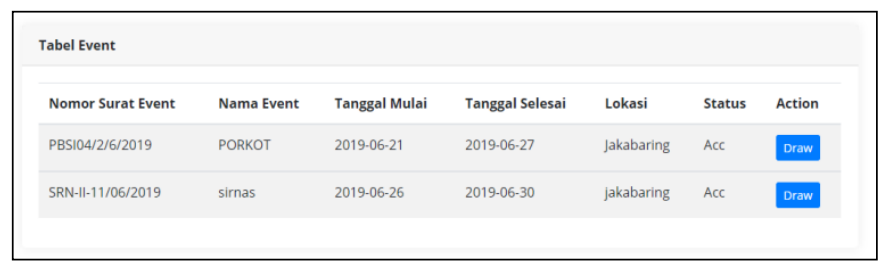

Gambar 9. Tampilan Draw Pertandingan

\subsubsection{Tampilan Rangking Atlet}

Tampilan dibawah ini merupakan tampilan halaman rangking atlet yang digunakan oleh pelatih untuk melakukan rangking atlet pada Sistem PBSI Kota Palembang. Berikut merupakan tampilan form rangking atlet sebagai berikut.

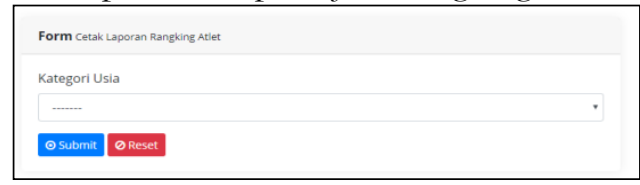

Gambar 10. Tampilan Rangking Atlet

\subsubsection{Tampilan Form Form Hasil Pertandingan}

Tampilan dibawah ini merupakan tampilan halaman hasil pertandingan yang digunakan oleh Keabsahan \& IT untuk melakukan hasil pertandingan pada Sistem PBSI Kota Palembang. Berikut merupakan tampilan form hasil pertandingan.

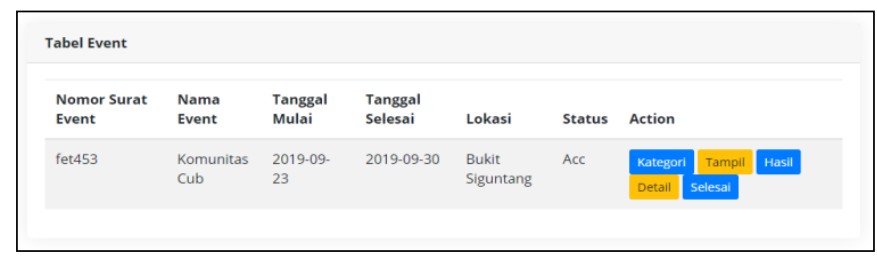

Gambar 11. Tampilan Form Hasil Petandingan

\section{SIMPULAN}

Berdasarkan uraian yang telah dijelas sebelumnya, maka dapat disimpulkan bahwa telah dihasilkan sebuah aplikasi perlombaan bulu tangkis untuk PBSI Kota Palembang yang diharapkan dapat membantu perlaksanaan lomba yang ada di PBSI Kota Palembang, sehingga atlet atau club bulu tangkis yang ada di Kota Palembang dapat mengakses website ini. Diharapkan juga atlet dapat mengetahu kapan akan terjadinya lomba, sehingga dapat mempersiapkan untuk mengikuti lomba tersebut dengan latihan lebih giat lagi. 


\section{REFERENCES}

[1] Yulianta \& Petrus Mursanto. Pengembangan Aplikasi Web dengan Iconix Process dan UML.. 2, Jakarta: Fakultas Ilmu Komputer - Universitas Indonesia, 2008, Jurnal Sistem Informasi, Vol. 4. 1412-8896.

[2] Sopiah, Nyimas \& Eka Puji Agustini. Penggunaan Metode Web Engineering dalam Aplikasi Penjualan Kain Khas Palembang. 2, Palembang: UBD-Press, 2019, Jurnal Matrik,Vol. 20. 1411-1624.

[3] Pressman, Roger S. Software Engineering: A Practitioner's Approach. New York: MCGraw-Hill, 2010.

[4] Maniah \& Hamidin, D. Analisis dan Perancangan Sistem Informasi: Pembahasan Secara Praktis dengan Contoh Kasus. Yogyakarta : Budi Utama, 2017. 